UDK 323.21(477)

DOI: https://doi.org/10.21564/2663-5704.50.235575

Polishchuk Ihor Oleksiiovych, Doctor of Political Science, Professor, Professor of Department of Sociology and Political Science, Yaroslav Mudryi

National Law University, Kharkiv, Ukraine, e-mail: i_polischuk@ukr.net

ORCID ID: 0000-0001-6864-4425

Maksimishyna Tetiana Mykolaivna, $\mathrm{PhD}$ in Political Science, Associate Professor of English Language Department, V. N. Karazin Kharkiv

National University, Ukraine

e-mail: tetyana.motornyuk@gmail.com

ORCID ID: 0000-0002-4134-1392

\title{
POLITICAL CULTURE OF THE MODERN WORLD: EPOCHAL TRANSFORMATIONS
}

The article is devoted to the topical problem of political and cultural transformations in the interaction between political power and its only source in democratic discourse, the people. This eternal problem of political science and policy is considered in chronological order in the global context and in today's Ukraine. In traditional societies, there was a remote and alienated coexistence of state institutions and the masses. The exception was the democratic republics of ancient polises. The modern era generates a contractual theory of the origin of the state, which considers the institutions of power as the result of a social agreement between the sovereign people and the governors. In the modern era in the middle of the twentieth century, the concept of the welfare state was formed. In the postmodern era, unstable life forces citizens to behave in relation to state power, depending on the actualization of a particular guise of their own existence. Citizens are losing a clear, unambiguous idea of state power, its functions, place and role in society.

Keywords: political culture, political power, authorities, people, transformations, modern World.

Formulation of the problem. The problem of political culture has long been the focus of political science, because its interpretive potential allows us to understand the specifics of political development and transit of a country. Among the key indicators that determine the nature of a political regime, the problem of the culture of interaction between political power and the masses occupies one of the leading places. This aspect of political culture is one of the most important, given that it determines the quality of the policy, its democracy or undemocracy. The 
place and role of the people in making and implementing strategic decisions of the political elite, the responsibility of politicians for these decisions, this issue is the subject of this article, which is built in such a way that first offers a retrospective of its global context, and then determines its Ukrainian specificity. The urgency of studying this problem is that Ukrainian society is actually facing the objective need for a global modernization breakthrough in the XXI century. The global context helps to understand the reference norms established in the world's polyarchies, and consideration of the Ukrainian specifics allows us to consider the place of Ukraine in the global political process and determine its real prospects in political transit.

Analysis of recent research and publications. The bibliography of this problem is really extensive. Ranging from the ancient thinkers Plato and Aristotle, the German philosopher-educator J. Herder to modern authors, among whom the Americans G. Almond and S. Verba managed to become classics of modern political science [1]. Modern ideas about the concept of "political culture" are taught by prominent political scientists J. Wiatr, P. Bourdieu, G. Sartori, J. Gray and D. Bell $[2 ; 3]$. A fairly complete overview of issues related to the political culture of Ukraine, Russia and other post-socialist countries, interesting sociological data are in the collection of articles by Ukrainian scholars from various fields of social science "Political culture: theory, problems, prospects" (Kyiv, 2004) and in collective works of leading Ukrainian sociologists and political scientists: "Political culture of the population of Ukraine" (Kyiv, 1993) and works of I. Yakovenko. Important issues of interaction between the people and the political authorities are raised in the works of Ukrainian scientists M. I. Mykhalchenko, D. I. Vydrin, A. Adamenko, V. M. Bebyk, M. I. Holovaty, M. Rozumny, M. Kuzmin, etc.

The purpose of the article is to define main transformations in the political culture of traditional and modern societies in the context of interaction between the political elite and the people. At the same time, special attention is paid to the specifics of political and cultural transformations of Ukrainian society.

Presenting main material. Before considering this issue, it is necessary to define the category of "political culture". In our opinion, political culture is a set of typical, relatively stable knowledge, ideas, guidelines, beliefs, values, orientations, patterns of behavior, symbols, formed as a result of historical experience of previous generations of national (social) community, transmitted from generation to generation, though having a significant transformational potential, it is manifested in the activities of the entities of the political process and in the functioning of political institutions [4, p. 66].

Global context. Traditional culture, which corresponds to the period of existence of traditional society, covers the longest period of development of human civilization (from ancient times to the $16^{\text {th }}$ century). In terms of time, the modern era (from the $16^{\text {th }}$ century to the $20^{\text {th }}$ century) is only an episode compared to the 
era of traditional society. Postmodernism (late $20^{\text {th }}$ century - early $21^{\text {st }}$ century) is only an era in the coordinates of traditional society. Traditional societies usually include tribal communities, societies of military democracy, Eastern despotism, ancient polises, medieval European monarchies [5, p. 85]. With the exception of the practice of interaction between society and authorities in ancient polises (democratic republics, where the principle of res publica - res populi "the state is a matter for the people") in other examples of traditional society we can see a remote, even alienated coexistence of state institutions and the masses. The rulers viewed society solely as a means of reproducing and ensuring their own material existence, and the people perceived power as the supreme institution, higher and unattainable for themselves.

The modern era gives rise to a fundamentally different political culture and state tradition. The main shift was that the theological views on the origin and nature of state power (all power from God) were replaced by a different philosophy of relations between the people and political power. There is a contractual theory of the origin of the state, which considers the institutions of power as the result of a social agreement between the sovereign people and the rulers, who must protect the natural human rights (right to private property, right to freedom of speech, right to life, etc.). Just revolutionary in its significance was the idea of J.-J. Rousseau on people's sovereignty [6], the essence of which is that the people (and no one else) is the only source of state power. In fact, the political culture of modernism is carrying out a renaissance of the ancient polis tradition. State power is not interpreted as something independent of society, but on the contrary as a phenomenon that is a derivative and official social institution. The philosophy of supremacy and alienation in the relationship between state power and the people, which was characteristic of the era of traditional society in the modern era, is replaced by the philosophy of interdependence and partnership between state power and its source, the people. Political power has ceased to be something alienated and independent of society. A liberal political and cultural tradition is being formed, which brings the people and state power to the same level: accountability and responsibilities of power to the people are postulated, rather than just the opposite.

If in the previous period (in the era of traditional society) the state power was essentially indifferent to the diversity of private practices of its subjects, because it existed, as already noted, somewhat separately; then in the modern era, when the state becomes an active subject of everyday life of citizens, it actively influences their lifestyle and individual existence. The doctrine of freedom is gradually being developed, which, according to John Gray, is based on a historically and culturally limited interpretation of the social and political entity [7]. This happens despite the fact that the principle of privacy and pluralism of their political views are widely postulated. 
The development of the state of the modern era reaches its apogee in the middle of the $20^{\text {th }}$ century with the emergence and implementation of the concept of the Welfare State. The essence of this concept was that all members of society should be provided through state regulation with all material goods and services that are necessary to ensure their normal functioning. The state sets a "subsistence minimum", i.e. a minimum level of income that allows any citizen to provide adequate food, clothing, footwear, housing, transportation, healthcare, culture, etc. The state takes care of the creation and maintenance of institutional norms and the boundaries of a socially oriented market economy, neutralizing the negative consequences for society of free competition. As M. M. Kuzmin notes, "figuratively speaking, the modern state, in the initial period of its existence performed the roles of lawyer, policeman and military officer, during the $19^{\text {th }}-20^{\text {th }}$ centuries became a part-time economist, doctor, teacher and generalized bearer of cultural qualities in the form of the concept of national states" [5, p. 86]. Thus, the welfare state is fully transformed into an institution that performs mainly the function of providing its citizens with a variety of services, among which management services in various spheres of social life are the main ones. In the political culture of welfare states with the maximum expansion of the voting rights of citizens in the $20^{\text {th }}$ century, activist guidelines are formed, because in order to receive quality services from the state it is necessary to actively influence its functioning.

The postmodern era begins at the end of the last century and continues to this day.

If modernism was considered by R. Aron and W. Rostow mostly as a socioeconomic and cultural system, which was dominated by industrial production and technology, there was an institutionalization of the division of labor, the rationalization of social relations; then postmodern in the concept of D. Bell is interpreted as a socio-economic and cultural system based on service economy, intellectual technology, knowledge as the main resource of production, pluralism of production organization, broad and intensive communications [8, p. 230-238].

To denote the phenomenon of modern society, scientists use a variety of terms and concepts that complement each other: the information age [9], the third wave [10], globalism [11; 12], post-industrial society [13;14], social and legal state [15] and humanistic law [16]. In it, the government exercises its influence on society through the state and law, a certain structure of government institutions, whose powers are determined by the principles of organization of legislative, executive and judicial power.

What are the features of postmodern political culture in the context of the relationship between citizens and the state?

According to V. M. Markovets, at the beginning of the $21^{\text {st }}$ century, political culture, as one of the components of general culture, is of great importance in the 
daily life of people. It includes some parts of the spiritual life directly related to political actions, ideas, evaluations, judgments, knowledge, beliefs, behavior, etc., which have been accumulated over the centuries and are now manifested in the direct political life of the individual, social groups or countries [17, c. 94].

Probably, it makes sense to talk about the general uncertainty and the rupture of the existence of individuals in our era, which means the actual marginality (from the Latin marginalis meaning border, roadside) of most people's culture and the process of marginalization of others. Obviously, today we are dealing with the fact that in a transitional society (the concept is applied to the whole global society and in general cannot even outline the features of a rapidly changing future) human transition to a new social environment is incomplete. As a result, we can see the loss of previous and non-acquisition of new permanent social ties by most individuals who cannot truly adapt to new living conditions. In today's world, marginalization has become the "norm" for the existence of a significant number of people who acquire the traits of ambivalent, bifurcated consciousness, lose political and social orientations and become the prey of political manipulation. The fleeting life in the postmodern era forces citizens to behave in relation to state power depending on the actualization of a particular incarnation of their own existence. Citizens are losing a clear, unambiguous idea of state power, its functions, place and role in society. This causes a crisis of participation. John Gray writes about this: "The alienation between the democratic electorate and political elites has now spread to all Western states, including the United States" [7, c. 79].

The activist culture of the modern era is followed by the marginal culture of the postmodern era. Citizens who cannot determine the value of the state as such, live in an uncertain social environment and it makes little sense for them to be politically active. Hence, we can predict in the near future that in postmodern political culture, the participation of citizens in socio-political life will develop in waves, in fact sine waves, depending on the specific situation and its significance for their interests. Moreover, ordinary voters, brought up in the previous modern era, are ready to accept mainly modernist cultural guidelines, they usually do not know and do not think about what scientists call the features of the postmodern era. The complexity of the relationship between the people and the state today is that citizens demand from governments clear explanations of a particular policy course, and statesmen sometimes simply do not have such explanations. According to M. M. Kuzmin, "the requirement of clarity and the factual impossibility of explanation is the main cultural conflict of the modern transition period" [5, c. 88].

Ukrainian political scientist M. M. Kuzmin notes: "The culture of a traditional society is characterized by the independence of the life world of political power and the life world of the rest of society. In the age of modernism on the one hand, power becomes an active actor in social processes, on the other hand it is 
perceived by society as a party to the relationship, which has clearly defined responsibilities. In postmodern relations, power and society take on a reactive character: a clearly structured order is lost, political actions become a reaction to the situation" $[5$, c. 85$]$.

In general, the state of post-industrial society (post-industrial state or state of the postmodern era) develops in two directions, i.e. internal and external. The internal functions of the post-industrial state are primarily aimed at the development of the information society, or the information technology society, and the external ones are aimed at the movement towards globalism, or a general planetary civilization. Thus, the post-industrial society has at least two dimensions: the information society (within the country) and globalism (in the international arena).

Ukraine: is it on the traditional roadside or in a general context? Ukraine has its own historical features, the main of which is that one of the largest European nations in its history has been mostly in a colonial and semi-colonial state. The Tatar-Mongol invasion, the Lithuanian and Polish protectorates during the Middle Ages, the tarriance of different territories of Ukraine in the Russian and AustroHungarian empires, the Holodomor (genocide) of the early 1930s in the USSR left their mark on the mental genetic code of the Ukrainian people. having formed the characteristic features of the colonial mentality, the main of which is the alienated attitude to power as such, the perception of socio-political life as something distant and remote.

At the same time, Ukraine has vivid episodes of a sovereign state tradition. These are the State of Rus (or Kievan Rus), the Galicia-Volyn State, the Cossack Republic, the Ukrainian People's Republic and the Western Ukrainian People's Republic. These states were characterized to some extent by common features that are signs of the Ukrainian national political culture, that is constitutionalism, democracy, regionalism, civilizational marginality, fragmentation, and so on. However, the interruption of the state tradition had a decisive influence on the political mentality of Ukrainians.

The difficult historical experience affected the consciousness of Ukrainians in another way: power was perceived as something sacred. In Ukraine, power has never been considered an institution, but embodied some higher social authority (or, conversely, an anarchic anti-ideal), and was not perceived as the embodiment of a rationally organized state. In our "national tradition", I. Yakovenko writes, "everything in the social space acquired the status of being only through the relationship with the government" [18, c. 49].

Ukraine's independence, which was proclaimed under the difficult conditions of the collapse of the Soviet Union in 1991, did not initially bring anything new to the culture of interaction between the people and the authorities. The weakness 
of the allied authorities led to the emergence of a powerful national liberation movement - the People's Movement of Ukraine. However, apart from the slogan of Ukraine's unconditional independence from Russia, this political force failed to offer a broad program of state-building. In this regard, Ukrainian political scientist V. Polokhalo notes: "In 1991, Ukraine raised its national flag without a real political and economic program of independent existence, as well as its own political philosophy. And today the Ukrainian state is in an uncertain state. The subject of internal discussions are not only the strategy and priorities of socioeconomic development, the principles of the political system, but even statehood as such" $[19$, p. 310$]$.

The authors of the fundamental work "Ukrainian Society" are right when they note: "In 1991, the Ukrainian state emerged as a state of the former party nomenklatura, which wanted to retain its power after the collapse of the USSR, under the guise of national ideology. It began to grow with the new Ukrainian oligarchy. These two subcultures were a significant part of the Ukrainian elite in the first decade of independence" [20, p. 149]. Therefore, it is not surprising that the main part of the population failed to get rid of the feeling of internal distance from power [21, p. 20].

This results in not entirely positive trends in the development of political consciousness of today's Ukrainian citizens. On August 3-5, 2006, the Institute of Social and Political Psychology of the Academy of Pedagogical Sciences of Ukraine conducted a mass survey. Its results were not entirely comforting - just over $21 \%$ of citizens consider Ukraine a truly independent state. Approximately the same result was obtained in the same period last year. But in September 2004, as the presidential election approached, not far more respondents considered Ukraine to be a truly independent state $-26 \%$. Recently, the number of those who think that Ukraine is not an independent state has increased: in 2004 there were $49.2 \%$; in 2005 there were almost 54\%; now there are about $63 \%$. Provided at the time of the poll, an all-Ukrainian referendum on Ukraine's independence were held again, the votes of citizens would be distributed as follows: for independence $-57.6 \%$; against independence $-27.1 \%$; more than $15 \%$ of respondents are still hesitant in their choice [22].

The semi-authoritarian regime created by the second President of Ukraine Leonid Kuchma was characterized by a phase of so-called "non-politics". This is what we had in the era of the previous president, who, in the words of political scientist V. Vydrin, "killed politics" by creating a regime where politics and business were one big feeding ground for a narrow circle of elected officials" [23, p. 45].

However, the first decade of independence brought positive changes in the worldview of the Ukrainian political elite: "Thirteen years of development in semi- 
authoritarian conditions during the presidencies of Leonid Kravchuk and Leonid Kuchma still contributed to a break with the former Bolshevik past, including attitudes to state paternalism" [20, p. 149].

Today we can state more or less objectively that the transition from Soviet authoritarianism to Ukrainian democracy was significantly complicated by the destruction in the previous period of such necessary elements of civil society (legal awareness, local self-government, economic sovereignty of citizens over the state, etc.). V. Kremen, D. Tabachnyk and V. Tkachenko note in this context: "The complexity of the situation is exacerbated by the fact that in Ukraine two dissimilar processes are intertwined. First, there is a transition from the position of one of the dependent regions of the superpower to the state of an independent state; secondly, the old authoritarian-bureaucratic system is destroyed and an attempt is made to establish a new model of social development, the main characteristics of which should be a mixed economy, political pluralism, civil society, rights and freedoms of speech" [24, p. 614].

The coexistence of these various subcultures was accompanied by mutual activation of their subjects and carriers, forms chronic, stagnant contradictions in the political process, exacerbating growing social tensions, irrational spending of power resources, increasing radicalism, disruption of communications, etc. [21, p. 33].

The situation erupted in 2004 when attempts to falsify the presidential election led Ukrainians, who had established the image of one of Europe's most indifferent nations, to take to the streets en masse to protest against the government's dishonesty and arbitrariness regarding their true expression of will.

After the 2004 presidential election, civil society in Ukraine received additional impetus in its development. This was clearly illustrated by the results of a February 2005 survey conducted by the American IFES Center in Ukraine (1,265 respondents). Compared to September 2003, the opinion of citizens about the importance of their right to vote has changed significantly. If then $70 \%$ thought that "their vote does not solve anything", then in February 2005 only $40 \%$ thought so $[23$, p. 82]. This is certainly an encouraging trend in the development of the electoral culture of Ukrainian citizens.

However, the achievements of the Orange Revolution are hardly to be exaggerated. As the following events showed, the main one among which is the revenge of the loser of the 2004 presidential election of Viktor Yanukovych in the parliamentary elections of 2006, when every third voter of Ukraine voted for his Party of Regions. Therefore, the announced democratic breakthrough turned out to be a democratic surge. At the same time, it should be emphasized that what happened 
in Ukraine during the Orange Revolution, according to V. Vydrin, is a reflection of the global trend of desecration of power. For many centuries, power was sacred in nature, it was considered a demigod, given from above, but from now on it was no longer worshiped and feared [23, p. 157].

Hence, it is hoped that Ukraine will finally surpass itself and be able to overcome the humiliating status of the periphery of globalization for a European nation of this scale and potential, and through integration into the European Union will become part of the world political process. Shifts in the political consciousness of citizens as a result of the Orange Revolution give grounds to predict the gradual establishment of the activist style in relation to politics and politicians, the democratization of relations between the people and the state elite.

Certain obstacles to the modernization of the political culture of modern Ukraine are its features such as regionalism and fragmentation. Ukraine is a country with significant regional features. Ukrainian regions (East, West, Center and South) differ significantly in many respects. Among them are geopolitical orientations, historical experience, regional mentality, social structure and ethnic composition of the population, its religious affiliation, etc. These indicators significantly affect the political consciousness of the population, the scale of its social values and guidelines. For example, according to O. Proskurina, "the originality of the regional political subculture of Donbass is due to: 1) the peculiarity of the historical character; 2) the depressed nature of the region and the unresolved nature of many important problems; 3 ) a combination of weakening democratic values, traditionalist and paternalistic traditions, with an electoral consciousness characterized by high expectations of democracy and power; 4) a high level of critical attitude towards local authorities; 5) high level of political participation of the population in comparison with other regions of the country; 6) clientele model of organization of elite groups, for which the social space is a personal agreement between the patrons of clientele. Some features of this subculture are due to the border nature of the region..." [25, p. 77].

The military actions of the Russian Federation against our state in eastern Ukraine, which began in 2014, had a negative impact on the processes of formation of a democratic political culture, actualized historical and regional problems. The fragmentation of Ukraine's political culture is characterized by a lack of citizens' consent to the political system of society, differences in understanding of power, lack of social consolidation, and a high level of distrust in state institutions. This type of political culture is characterized by such features as the use of violence, a high level of conflict, the lack of generally accepted effective procedures to resolve conflicts, and the instability of government. Excessive fragmentation of political culture is the cause of instability in society as a whole. 
N. M. Semke also highlights such a feature of modern political culture of Ukraine as ambivalence. The researcher notes that "ambivalence is manifested in the focus on mutually exclusive values and norms, in the contradictory combination of democratic goals and totalitarian means of their implementation. A person endowed with ambivalent consciousness is able to advocate for integration into the EU and the Eurasian market, for the revival of the Ukrainian language but with the preservation of the Russian language as the state language, for the development of Ukrainian culture but with the preservation of the dominant position of Russian culture" [26, p. 57].

If we consider the prospects for Ukraine's development in the postmodern era, we should consider somewhat late nature of national modernization compared to other developed countries. Probably the most suitable for predicting the Ukrainian perspective is the theory of cycles. Sociologists now distinguish various cycles of development, based on the historical experience of a country. Analyzing the history of Ukraine, we made the following interesting observation: turning points occur every 100 years. 1917 was in many ways a turning point not only for Russia, but also for Ukraine and all mankind. From here, we can predict that the next turning point will take place in 2017. The head of the research committee "Theory of Social Systems" at the Russian Society of Sociologists A. Davydov claims that in any cycle, $67 \%$ of its duration falls on the growth phase, and $33 \%$ falls on the phase of restructuring. Thus, the phase of growth of the age cycle began in 1917 and ended in 1984. The duration of restructuring will take 33 years" [27, p. 43].

Thus, according to the theory of cycles, the most important socio-economic and political transformations will take place around 2008-2009, when Ukraine as a system will reach a qualitatively new level. It should be mentioned that the next elections of the President of Ukraine are to take place in 2009, which will be decisive in this context. The cycle, which began in 1917 with the slogan "Plunder the loot!", lasted until 1984 under the sign of a constant increase in production capacity through non-economic coercion and latent exploitation of workers. In 1984, a new stage of restructuring began, the essence of which was the redistribution of the loot among members. In one form or another, this stage has been continuing up to now.

Conclusions. Drawing a line, we can make the following conclusions from our work.

1. If in a traditional society the philosophy of supremacy and alienation prevailed in the relationship between state power and the people, then in the modern era a fundamentally new philosophy has formed, i.e. interdependence and partnership between state power and its source, the people. Political power has ceased to be something alienated and independent of society. 
2. Activist guidelines dominate in the political culture of welfare states - the apogee of the development of the modern state with the maximum expansion of citizens' suffrage in the $20^{\text {th }}$ century, because in order to receive quality services from the state it is necessary to actively influence its functioning.

3. In postmodern political culture, the participation of citizens in socio-political life is likely to develop in waves, sine waves, depending on the specific situation and its significance for their interests.

4. The political culture of modern Ukraine as one of its important components contains an ambivalent attitude towards the state on the part of citizens. Ukrainian citizens have learned to "tick off the authorities" (the Orange Revolution of 2004, the Revolution of Dignity of 2013-2014), but do not yet have the usual mechanisms to influence powerful people in non-crisis situations for a developed democracy. At the same time, the prospect of real democratization of Ukraine after 2014 seems quite probable.

5. Mainly the prospect of European integration will allow independent Ukraine to finally get rid of the status of the periphery of globalization and join the family of developed European nations that build their own political life on the principles of democracy, civil liberties and human rights.

\section{REFERENCES}

1. Almond, G., \& Verba, S. (1989). The Civic Culture: Political Attitudes and Democracy in Five Nations. New York: SAGE.

2. Wiatr, J. (2000). Socjaldemokracja wobec wyzwan XXI wieku. Warszawa: LCP.

3. Sartori, G. (1977). Parties and Party Systems: A Framework for Analysis. London: Cambridge University Press.

4. Polischuk, I. O. (2016). Osnovni pidkhody do analizu politychnoi kultury yak vazhlyvoi skladovoi analizu demokratychnykh peretvoren. S. P. A. C.E., (1). http://space.onua.edu.ua/index.php/space/article/view/13 [in Ukranian].

5. Kuzmin, N. N. (2005). Transformatsii i tipologia otnoshenii vlasti I obshchestva: traditsionnaia kultura, modern, postmodern. Methodology, theory and practice of sociological analysis of modern society: A collection of scientific papers. Kharkiv: KhNU [in Russian].

6. Rousseau, J.-J. (1999). Ob obshchestvennom dogovore. In H. H. Demidenko (Ed.), History of political and legal doctrines. Kharkiv: Pravo [in Russian].

7. Gray, J. (2003). Pominki po prosveshcheniiu: Politika i kultura na zakate sovremennosti. Moscow: Praxis [in Russian].

8. Bell, D. (1996). Prykhid postindustrialnoho suspilstva. In Modern foreign philosophy. Kyiv: Wakler [in Ukranian]. 
9. Meliukhin, I. S. (1999). Informatsyonnoie obshchestvo: istoki, problem, tendentsii razvitia. Moscow: Moscow University Publishing House [in Russian].

10. Toffler, E. (1999). Trietia volna. Moscow: LLC “AST Firm Publishing House" [in Russian].

11. Panarin, A. S. (2000). Iskushenie globalizmom. Moscow: EKSMO [in Russian].

12. Martin, H.-P., \& Schumann, H. (2001). Zapadnia globalizatsii: ataka na protsvetanie i demokratiu. Moscow: Alpina [in Russian].

13. Bell, D. (1999). Griadushcheie postindustrialnoie obshchestvo. Moscow: Academy [in Russian].

14. Inoziemtsev, V. L. (2000). Sovremennoie postindustrialnoie obshchestvo: priroda, protivorechiia, perspektivy. Moscow: Logos [in Russian].

15. Skrypniuk, O. V. (2000). Sotsialna, pravova derzhava v Ukraini: problem teorii i praktyky. Kyiv: V. M. Koretskyi Institute of State and Law [in Ukranian].

16. Alekseiev, O. S. (2001). Voskhozhdeniie k pravu. Moscow: Norma [in Russian].

17. Markovets, V. M. (2017). Politychna kultura yak skladova dukhovnoi kultury suspilstva. Investments: practice and experience, 18 [in Ukranian].

18. Yakovenko, I. G. (1992). Russkaia intelligentsia kak promezhutochnyi sotsiokulturnyi tip. In The dynamics of cultural and social ties. Moscow: IP RAS [in Russian].

19. Dergachev, A., et al. (1996). Ukrainskaia gosudarstvennost v 20 veke: istorikopoliticheskii analiz. Kyiv: Political thought [in Russian].

20. Vlasyk, O. S., Krysachenko, V. S., \& Stepyko, M. T. (2005). Ukrainskyi sotsium. Kyiv: Knowledge of Ukraine [in Ukranian].

21. Vedeneiev, V. A. (2002). Politicheskaia kultura postsovetskikh obshchestv: traditsii, liberalnye tsennosti i perspektivy. Kryvyi Rih: Mineral [in Russian].

22. Lyshe $21 \%$ hromadian vvazhaiut Ukrainu nezalezhnoiu. (2006, September 19). Den [in Ukranian].

23. Adamenko, A. Y., \& Vydrin, D. I. (2006). Vspominaia Artkhashastru - Recalling Arthashastra. Kyiv: Genesa [in Russian]

24. Kremen, V. H., Tabachnyk, D. V., \& Tkachenko, L. V. (1996). Ukraina: alternatyvy postupu (krytyka istorychnoho dosvidu). Kyiv: ARC-UKRAINE [in Ukranian].

25. Proskurina, O. (2008). Polityko-kulturnyi vymir Donbaskoho rehionu. Political management, 29(2) [in Ukranian].

26. Semke, N. M. (2016). Osoblyvosti politychnoi kultury suchasnoi Ukrainy. Bulletin of NTU “KhPI”. Series: Actual problems of development of the Ukrainian society, 40(1212) [in Ukranian].

27. Tsyklichnost v sotsialnykh sistemakh ("kruglyi stol”). (1992). Sociological research, 6 [in Russian]. 
Полішук Ігор Олексійович, доктор політичних наук, професор, професор кафедри соціології та політології, Національний юридичний університет імені Ярослава Мудрого, м. Харків, Україна

\section{Максімішина Тетяна Миколаӥвна, кандидат політичних наук, доцент} кафедри англійської мови, Харківський національний університет імені В. Н. Каразіна, Україна

\section{ПОЛІТИЧНА КУЛЬТУРА СУЧАСНОГО СВІТУ: ЕПОХАЛЬНІ ТРАНСФОРМАЦІї}

Постановка проблеми. Проблема політичної культури тривалий час знаходиться у фокусі уваги політичної науки, адже ї̈ інтерпретаційний потенціал дозволяє зрозуміти специфіку політичного розвитку та транзиту тієї чи іншої краӥни. Серед ключових індикаторів, щзо визначають природу того чи іншого політичного режиму, проблема культури взаємодії між політичною владою та народними масами посідає одне з чільних місиь. Цей аспект політичної культури $\epsilon$ одним із найголовніших з огляду на те, що він визначає якість проваджуваної політики, ї̈ демократичність або недемократичність.

Аналіз останніх досліджень і публікацій. Бібліографія цієї проблеми вельми обширна, починаючи з античних мислителів Платона і Аристотеля, німецького філософа-просвітника Й. Гердера і закінчуючи сучасними авторами, серед яких встигли стати класиками сучасної політології американиі Г. Алмонд, С. Верба. Сучасні уявлення про поняття «політична культура» викладаються видатними політологами С. Вятром, П. Бурдьє, Дж. Сарторі, Д. Греєм, Д. Беллом. Важливі проблеми взаємодї між народом та політичною владою порущуються в роботах украйнських учених М. І. Михальченка, Д. І. Видріна, А. Адаменко, В. М. Бебика, М. І. Головатого, В. Д. Ребкала, В. О. Вєдєнєєва, В. Матусевича, В. С. Ясинської, М. Розумного, М. Кузьміна та ін.

Мета статті полягає в тому, щоби скласти дефініцію та визначити основні трансформації політичної культури традиційних та сучасних сочіумів у контексті взаємодії між політичною елітою та народом. При цьому окремої уваги приділяється розгляду специфіки політико-культурних трансформацій украӥнського суспільства.

Виклад основного матеріалу. У контексті теорії суспільств Е. Тофлера аналізується філософія стосунків та політична культура між народом та його правителями. Визначаються основні політико-культурні проблеми та перспективи розвитку Української держави в контексті ї̈ європейської інтеграчії. Розкриваються головні тренди політико-культурного розвитку постмодерних суспільств.

Висновок. У постмодерністській політичній культурі, швидще за все, участь громадян у суспільно-політичному житті розвиватиметься «хвилями», за синусоїдою, залежно від конкретної ситуачї̈ та ї̈ значення для їхніх інтересів. 
Ключові слова: політична культура, політична влада, влада, народ, трансформації, сучасність.

Полищук Игорь Алексеевич, доктор политических наук, профессор, профессор кафедры социологии и политологии, Национальный юридический университет имени Ярослава Мудрого, г. Харьков, Украина

Максимишина Татьяна Николаевна, кандидат политических наук, доцент кафедры английского языка, Харьковский национальный университет имени В. Н. Каразина, Украина

\section{ПОЛИТИЧЕСКАЯ КУЛЬТУРА СОВРЕМЕННОГО МИРА: ЭПОХАЛЬНЫЕ ТРАНСФОРМАЦИИ}

Статья посвящена актуальной проблеме политико-культурных трансформаций во взаимодействии между политической властью и ее единственным источником в демократическом дискурсе - народом. Эта вечная проблема политической науки и практики рассматривается в хронологической последовательности в общемировом контексте и в условиях нынешней Украины. В традиционных обществах наблюдалось отстраненное и отчужденное сосуществование государственно-властных институтов и народных масс. Исключение составляли демократические республики античных полисов. Эпоха модерна порождает договорную теорию происхождения государства, которая рассматривает институты власти как итог общественного договора между суверенным народом и правителями. В эпоху модерна, в середине $X X$ в., формируется кониепиия государства благосостояния. В постмодерную эпоху нестабильная жизнь заставляет граждан вести себя по отношению к государственной власти в зависимости от актуализаџии той или иной ипостаси собственного бытия. У граждан теряется четкое, однозначное представление о государственной власти, ее функииях, месте и роли в жизни соииума.

Ключевые слова: политическая культура, политическая власть, власти, народ, трансформачии, современность.

\section{$\operatorname{soc}$}

